\title{
Gene expression signature of estrogen receptor $\alpha$ status in breast
}

\section{cancer}

\author{
Martín C Abba ${ }^{1}$, Yuhui Hu${ }^{1}$, Hongxia Sun${ }^{1}$, Jeffrey A Drake ${ }^{1}$, Sally Gaddis ${ }^{1}$, \\ Keith Baggerly², Aysegul Sahin ${ }^{3}$ and C Marcelo Aldaz*1
}

\begin{abstract}
Address: ${ }^{1}$ Department of Carcinogenesis, The University of Texas M.D. Anderson Cancer Center, Science Park-Research Division, Smithville, Texas, USA, ${ }^{2}$ Department of Biostatistics, The University of Texas M.D. Anderson Cancer Center, Houston, Texas, USA and ${ }^{3}$ Department of Pathology, The University of Texas M.D. Anderson Cancer Center, Houston, Texas, USA

Email: Martín C Abba - mabba777@hotmail.com; Yuhui Hu - yhhu@mdanderson.org; Hongxia Sun - hcsun@mdanderson.org; Jeffrey A Drake - jadrake@mdanderson.org; Sally Gaddis - sgaddis@mdanderson.org; Keith Baggerly - kabagg@mdanderson.org; Aysegul Sahin - asahin@mdanderson.org; C Marcelo Aldaz* - maldaz@odin.mdacc.tmc.edu

* Corresponding author
\end{abstract}

Published: II March 2005

BMC Genomics 2005, 6:37 doi:10.1186/147|-2164-6-37

This article is available from: http://www.biomedcentral.com//47/-2/64/6/37

(C) 2005 Abba et al; licensee BioMed Central Ltd.

This is an Open Access article distributed under the terms of the Creative Commons Attribution License (http://creativecommons.org/licenses/by/2.0), which permits unrestricted use, distribution, and reproduction in any medium, provided the original work is properly cited.
Received: 03 November 2004

Accepted: II March 2005

\begin{abstract}
Background: Estrogens are known to regulate the proliferation of breast cancer cells and to modify their phenotypic properties. Identification of estrogen-regulated genes in human breast tumors is an essential step toward understanding the molecular mechanisms of estrogen action in cancer. To this end we generated and compared the Serial Analysis of Gene Expression (SAGE) profiles of 26 human breast carcinomas based on their estrogen receptor $\alpha$ (ER) status. Thus, producing a breast cancer SAGE database of almost 2.5 million tags, representing over 50,000 transcripts.
\end{abstract}

Results: We identified 520 transcripts differentially expressed between ER $\alpha$-positive $(+)$ and ER $\alpha-$ negative (-) primary breast tumors (Fold change $\geq 2$; $p<0.05$ ). Furthermore, we identified 220 highaffinity Estrogen Responsive Elements (EREs) distributed on the promoter regions of 163 out of the 473 up-modulated genes in ER $\alpha(+)$ breast tumors. In brief, we observed predominantly upregulation of cell growth related genes, DNA binding and transcription factor activity related genes based on Gene Ontology (GO) biological functional annotation. GO terms over-representation analysis showed a statistically significant enrichment of various transcript families including: metal ion binding related transcripts $(p=0.01 \mathrm{I})$, calcium ion binding related transcripts $(\mathrm{p}=0.033)$ and steroid hormone receptor activity related transcripts $(p=0.03 \mathrm{I})$. SAGE data associated with ER $\alpha$ status was compared with reported information from breast cancer DNA microarrays studies. A significant proportion of $E R \alpha$ associated gene expression changes was validated by this crossplatform comparison. However, our SAGE study also identified novel sets of genes as highly expressed in $E R \alpha(+)$ invasive breast tumors not previously reported. These observations were further validated in an independent set of human breast tumors by means of real time RT-PCR.

Conclusion: The integration of the breast cancer comparative transcriptome analysis based on ER $\alpha$ status coupled to the genome-wide identification of high-affinity EREs and GO overrepresentation analysis, provide useful information for validation and discovery of signaling networks related to estrogen response in this malignancy. 


\section{Background}

Estrogen plays essential roles in the development, growth control and differentiation of the normal mammary gland. However, it is well documented that endogenous estrogens are powerful mitogens critical for the initiation and progression of human breast and gynecological cancers [1]. This cell proliferation signal is mediated by the estrogen receptors (ER), members of the nuclear receptor family that function both as signal transducers and transcription factors to modulate expression of target genes [2]. There are two main subtypes of estrogen receptors: ER $\alpha$ and ER $\beta$ that generally can form homo- and heterodimers before binding to DNA. Although the DNA binding domains of these receptors are very similar, the overall degree of homology is low [3].

Transcriptional regulation of target genes in response to $17 \beta$-estradiol $\left(\mathrm{E}_{2}\right)$ is mediated by two main mechanisms. In one, the $\mathrm{E}_{2}$-ER complex binds to a specific DNA sequence called the estrogen response element (ERE), this receptor-ligand DNA bounded complex interacts with coregulatory proteins, promoting chromatin remodeling and bridging with the general gene transcription machinery thus resulting in transcription initiation [4]. Alternatively, the ligand-ER complex can interact with other DNA-bound transcription factors that in turn bind DNA sequences (e.g. via AP1, SP1 complexes) [5,6]. ER $\alpha$ and ER $\beta$ have different affinities for different response elements and exhibit distinct transcriptional properties. Additionally, $\mathrm{E}_{2}$ also exerts rapid, non-genomic effects attributed to cell membrane-initiated signaling [7].

Approximately two-thirds of all breast cancers are ER $\alpha(+)$ at the time of diagnosis and expression of this receptor is determinant of a tumor phenotype that is associated with hormone-responsiveness. Patients with tumors that express ER $\alpha$ have a longer disease-free interval and overall survival than patients with tumors that lack ER $\alpha$ expression [8]. However, the association between ER $\alpha$ expression and hormonal responsiveness is not perfect: approximately $30 \%$ of ER $\alpha$-positive tumors are not hormone-responsive while $5-15 \%$ of ER $\alpha$-negative tumors respond to hormonal therapy [9]. The molecular basis for the association between ER $\alpha$ expression, hormonal responsiveness and breast cancer prognosis remains unclear.

Several studies have been carried out using cDNA and oligonucleotide microarrays identifying breast cancer subclasses possessing distinct biological and clinical properties [10-13]. Among the distinctions made to date, the clearest separation was observed between ER $\alpha(+)$ and $\mathrm{ER} \alpha(-)$ tumors [10-15]. It has been suggested that there are sets of genes expressed in association with ER $\alpha$ that could play an important role in determining the hor- mone-responsive breast cancer phenotype [16]. ER $\alpha$ is obviously likely to be important for the $\mathrm{E}_{2}$ induced proliferative response predominantly via the regulation of estradiol-responsive genes. Nevertheless, the expression of additional subsets of genes not necessarily directly regulated by estrogen may also be fundamental in defining the breast cancer hormone-responsive phenotype.

To further elucidate the molecular basis of estrogendependent breast carcinogenesis, we here report a comparative transcriptome profiling of invasive breast tumors based on ER $\alpha$ status obtained by SAGE. The SAGE method provides a statistical description of the mRNA population present in a cell without prior selection of the genes to be studied, and this constitutes a major advantage [17]. The breast cancer SAGE comparative analysis was combined with promoter sequence analysis of genes of interest using high-throughput methods of high-affinity ERE identification. In order to have an even more comprehensive picture we also performed a cross-platform comparison between SAGE and DNA microarray studies.

\section{Results and discussion \\ Biomarkers of ER $\alpha$ status in breast carcinomas}

The primary goal of our study was to identify the most commonly deregulated genes in invasive breast carcinomas related to ER $\alpha$ status. To this end SAGE data was obtained from a set of primary breast carcinomas. Thus, a breast cancer SAGE database of almost 2.5 million tags was analyzed, representing over 50,000 tag species. We performed a comprehensive evaluation and comparison of gene expression profiles using a recently developed supervised method [18], to identify the most representative differentially expressed transcripts between tumors groups, i.e. $\mathrm{ER} \alpha(+)$ vs. $\mathrm{ER} \alpha(-)$ breast tumors.

This statistical analysis revealed 520 genes differentially expressed (Fold change $\geq 2 ; \mathrm{p}<0.05$ ) between ER $\alpha(+)$ and ER $\alpha(-)$ primary breast carcinomas (see additional data file 1). Among the 520 transcripts, 473 were up-modulated and 47 were down-modulated transcripts in ER $\alpha$ $(+)$ tumors.

The most commonly over-expressed transcripts in ER $\alpha(+)$ tumors were: trefoil factor 1 (TFF1/pS2), synaptotagmin-like 4 (SYTL4), regulating synaptic membrane exocytosis 4 (RIMS4), dual specificity phosphatase 4 (DUSP4), chromosome 1 open reading frame 34 (C1orf34), necdin homolog $(N D N), n$-acetyltransferase 1 (NAT1) and caspase recruitment domain family 10 (CARD10) (Table 1 and additional data file 1).

To validate novel ER $\alpha$ associated genes detected by SAGE not reported in other studies, we performed Real Time RTPCR analysis of representative transcripts in an 
Table I: Most highly up-modulated transcripts in ER $\alpha(+)$ breast carcinomas identified by SAGE.

\begin{tabular}{|c|c|c|c|c|}
\hline Gene name & Tag & Locus Link & Fold change ( $p$ value) & Frequency\# \\
\hline \multicolumn{5}{|l|}{ Cell proliferation related } \\
\hline TFFI* (trefoil factor I) & CTGGCCCTCG & 7031 & $51.4(0.0016)$ & $15 / 18(83 \%)$ \\
\hline DUSP4 (dual specificity phosphatase 4) & CGGGCAGAAA & 1846 & $14.7(0.0016)$ & $14 / 18(78 \%)$ \\
\hline NDN* (necdin homolog) & ACCTTGCTGG & 4692 & $13.3(0.0026)$ & $11 / 18(61 \%)$ \\
\hline HDGFRP3 (hepatoma-derived growth factor) & TGTAAAGTTT & 50810 & $9.8(0.0019)$ & $12 / 18(67 \%)$ \\
\hline TSPANI* (tetraspan I) & GGAACTGTGA & 10103 & $9.5(0.0017)$ & $15 / 18(83 \%)$ \\
\hline SEP6 (septin 6) & TCAATTTTCA & 23157 & $7.6(0.0044)$ & $12 / 18(67 \%)$ \\
\hline DHX34* (DEAH box polypeptide 34) & GTTGCTCACT & 9704 & $7.1(0.0129)$ & $9 / 18(50 \%)$ \\
\hline \multicolumn{5}{|l|}{ Apoptosis related } \\
\hline CARDI0* (caspase recruitment domain family) & AGAATGTACG & 29775 & II.I (0.0030) & $15 / 18(83 \%)$ \\
\hline \multicolumn{5}{|l|}{ Signal transduction related } \\
\hline SYTL4* (synaptotagmin-like 4) & TATGTGTGCT & 94121 & $28.0(0.0003)$ & $15 / 18(83 \%)$ \\
\hline ECMI* (extracellular matrix protein I) & ACTGCCCGCT & 1893 & $10.1(0.0175)$ & $13 / 18(72 \%)$ \\
\hline LEPR* (leptin receptor) & AAAGTTTGAG & 3953 & $9.8(0.0302)$ & $10 / 18(55 \%)$ \\
\hline PTGES (prostaglandin E synthase) & TGAGTCCCTG & 9536 & $8.0(0.0168)$ & $8 / 18(44 \%)$ \\
\hline SCUBE2 (signal peptide, CUB domain EGF-like 2) & TCAGCACAGT & 57758 & $7.5(0.0024)$ & $14 / 18(78 \%)$ \\
\hline ADORA2A* (adenosine A2a receptor) & TGCTGAGTAG & 135 & $7.1(0.0460)$ & $11 / 18(61 \%)$ \\
\hline ITGBLI (integrin beta-like I) & CATATTCACA & 9358 & $7.1(0.0159)$ & $8 / 18(44 \%)$ \\
\hline \multicolumn{5}{|l|}{ Regulation of transcription related } \\
\hline ESRI (estrogen receptor I) & AGCAGGTGCC & 2099 & $9.8(0.0000)$ & $18 / 18(100 \%)$ \\
\hline TCEALI (transcriptional elongation factor A) & AAAGATGTAC & 9338 & $9.8(0.0014)$ & $13 / 18(72 \%)$ \\
\hline ZNFI4 (zinc finger protein 14) & TAAACAGCCC & 7561 & $8.4(0.0023)$ & $13 / 18(72 \%)$ \\
\hline ZNF38* (zinc finger protein 38) & CCAGCATTAC & 7589 & $7.6(0.0051)$ & $10 / 18(55 \%)$ \\
\hline HIFIAN* (hypoxia-inducible factor I $\alpha$ subunit inhibitor) & CCTGAGTGCG & 55662 & $7.1(0.0094)$ & $10 / 18(55 \%)$ \\
\hline HOXCI3 (homeo box $\mathrm{Cl} 3$ ) & TTTTTAAAAT & 3229 & $7.1(0.0157)$ & $9 / 18(50 \%)$ \\
\hline \multicolumn{5}{|l|}{ Cytoskeleton } \\
\hline MAPT (microtubule-associated protein tau) & GTAGACTCGC & 4137 & $9.8(0.0085)$ & $9 / 18(50 \%)$ \\
\hline MYLIP (myosin regulatory light chain interacting) & TTTTCСACTC & 29116 & $9.3(0.0036)$ & $11 / 18(61 \%)$ \\
\hline \multicolumn{5}{|l|}{ Metabolism and Miscelaneous } \\
\hline RIMS4 (regulating synaptic membrane exocytosis) & TTGAAATTAA & 140730 & $24.9(0.0378)$ & $8 / 18(44 \%)$ \\
\hline NATI (N-acetyltransferase I) & TATCTTCTGT & 9 & $11.7(0.0385)$ & $15 / 18(83 \%)$ \\
\hline ATP6VIBI* (ATPase, $\mathrm{H}+$ transporting) & ССТСССССТС & 525 & $10.7(0.0111)$ & $10 / 18(55 \%)$ \\
\hline JDPI (J domain containing protein I) & TCTGTGAATT & 56521 & $10.0(0.0035)$ & $12 / 18(67 \%)$ \\
\hline CHSTII (carbohydrate sulfotransferase II) & ААССТТССТС & 50515 & $9.8(0.0009)$ & $13 / 18(72 \%)$ \\
\hline CILP (nucleotide pyrophosphohydrolase) & GTTTTGCCCA & 8483 & $9.3(0.0054)$ & $14 / 18(78 \%)$ \\
\hline ABCA3 (ATP-binding cassette sub-family A) & GTAGTCACCG & 21 & $8.9(0.0149)$ & $10 / 18(55 \%)$ \\
\hline SECI4L2 & GGAAGGCGGC & 23541 & $8.7(0.0487)$ & $9 / 18(50 \%)$ \\
\hline ANXA9* (annexin A9) & ACATCCGAGG & 8416 & $8.4(0.0145)$ & $10 / 18(55 \%)$ \\
\hline KCTD3 (K channel tetramerisation domain 3) & ATAATTAAAT & 51133 & $8.4(0.0001)$ & $17 / 18(94 \%)$ \\
\hline SFRS7 (splicing factor) & TAGCTAATAT & 6432 & $8.0(0.0031)$ & $12 / 18(67 \%)$ \\
\hline SNRPA* (small nuclear ribonucleoprot. polypep. A) & AAGATCTCCT & 6626 & $7.6(0.0009)$ & $15 / 18(83 \%)$ \\
\hline NNMT (nicotinamide N-methyltransferase) & CCTGCAATTC & 4837 & $7.6(0.0120)$ & $10 / 18(55 \%)$ \\
\hline SLCIA4 (solute carrier family I member 4) & GACTCACAGG & 6509 & $7.6(0.0254)$ & $9 / 18(50 \%)$ \\
\hline TIPARP (TCDD-inducible polymerase) & AAATGGCCAA & 25976 & $7.6(0.0051)$ & $10 / 18(55 \%)$ \\
\hline SLC7A2 (solute carrier family 7 member 2) & CACTGACAGC & 6542 & $7.3(0.0190)$ & $11 / 18(61 \%)$ \\
\hline GA* (liver mitochondrial glutaminase) & CTGCTGCTAC & 27165 & $7.1(0.0126)$ & $9 / 18(50 \%)$ \\
\hline \multicolumn{5}{|l|}{ Function unknown } \\
\hline Clorf34 & AGGATGTACA & 22996 & $13.3(0.0025)$ & $14 / 18(78 \%)$ \\
\hline SMILE (hypothetical protein FLJ90492) & TAGAGAGTTT & 160418 & II.I (0.0004) & $15 / 18(83 \%)$ \\
\hline
\end{tabular}


Table I: Most highly up-modulated transcripts in ER $\alpha(+)$ breast carcinomas identified by SAGE. (Continued)

\begin{tabular}{lrrrr}
\hline RHBDL4 (rhomboid, veinlet-like 4) & TTGTTTCTAA & 162494 & $10.7(0.0099)$ & $9 / 18(50 \%)$ \\
KIAA0882 & GTCTCATTTC & 23158 & $10.1(0.0007)$ & $18 / 18(100 \%)$ \\
C20orf103* & TTTAGTGATT & 24141 & $9.3(0.0277)$ & $10 / 18(55 \%)$ \\
FLJ33387 & GCAGGGAGAG & 161145 & $9.3(0.0118)$ & $10 / 18(55 \%)$ \\
TRALPUSH & GTTTCCAGAG & 116931 & $8.9(0.0458)$ & $9 / 18(50 \%)$ \\
KIAA0980* & TGGTGCTTCC & 22981 & $7.6(0.0096)$ & $11 / 18(61 \%)$ \\
CIOorf32 & AGTCTGTTGT & 119032 & $7.3(0.0002)$ & $15 / 18(83 \%)$ \\
FLJ136II & TAATCACACT & 80006 & $7.1(0.0069)$ & $10 / 18(55 \%)$ \\
\hline
\end{tabular}

* Genes with known or putative high-affinity EREs mapping in the vicinity of the TSS.

\# Transcripts tags changing $>2$-fold when compared with the average expression of ER (-) tumors in at least 8 of I8 (44\%) ER $\alpha(+)$ invasive carcinomas SAGE libraries.

For the whole list of ER $\alpha$ associated transcripts see additional data file I.

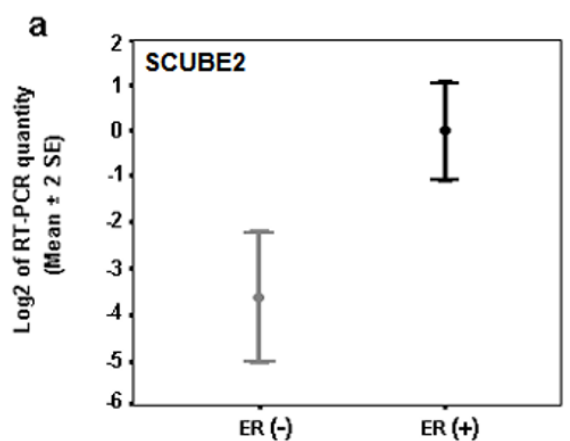

b
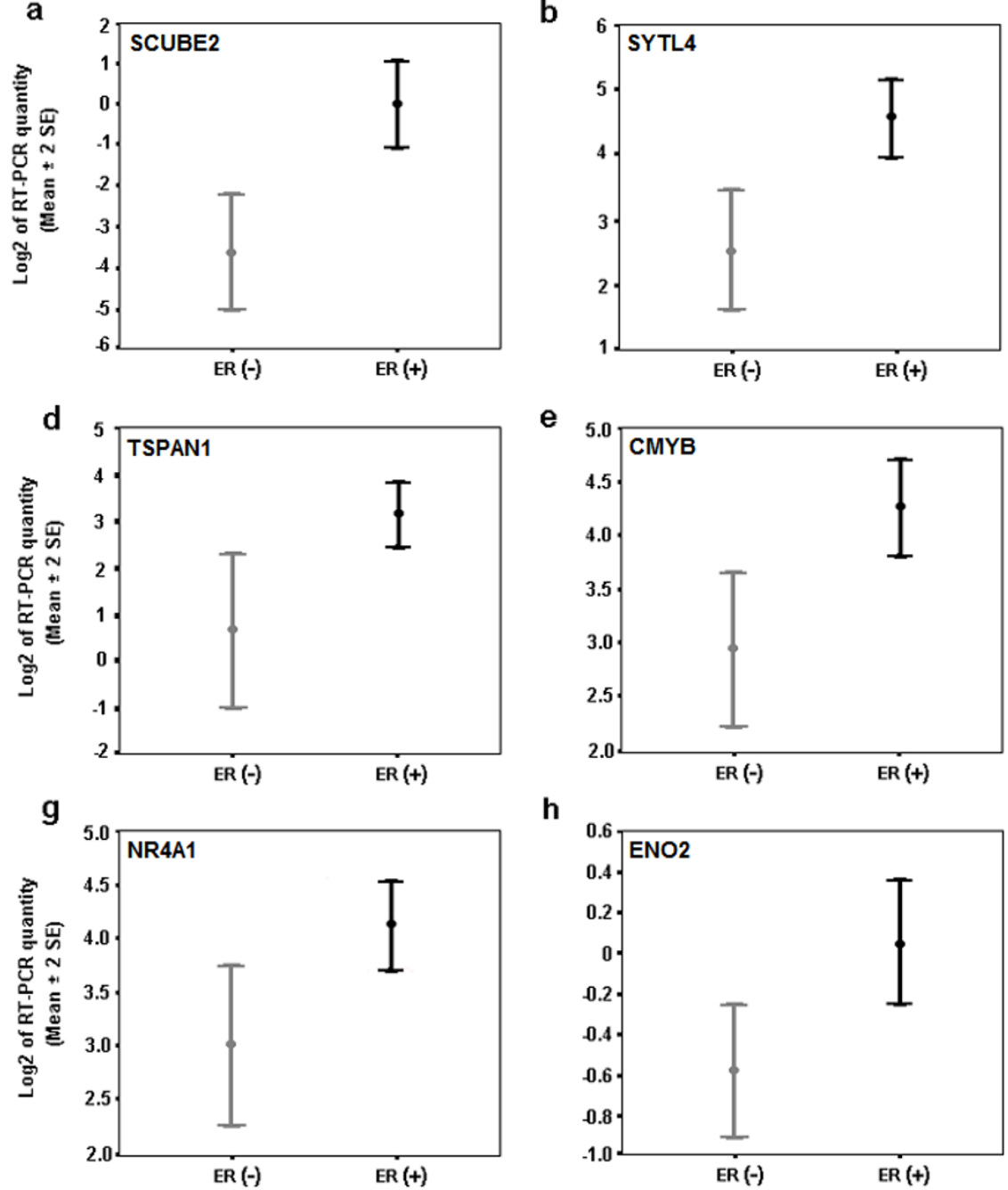

e

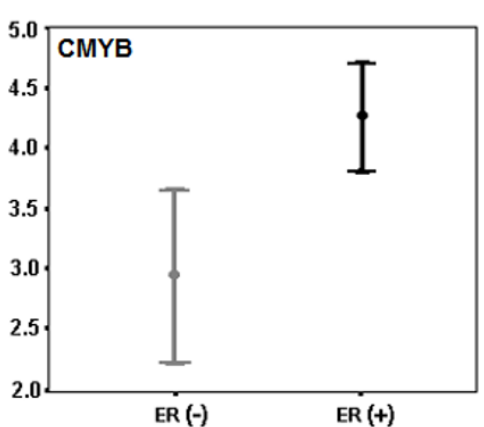

h

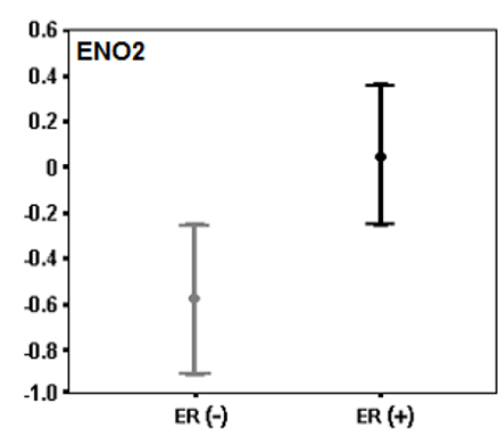

c

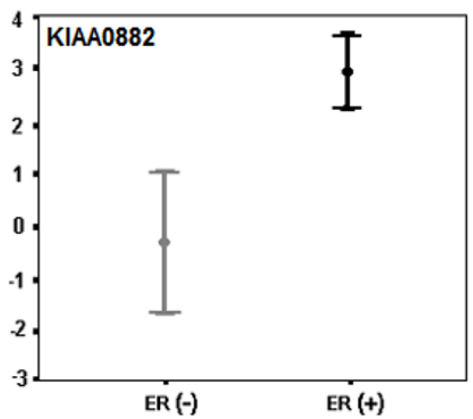

f

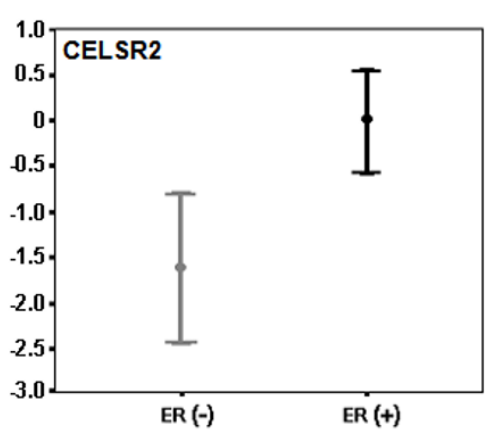

i

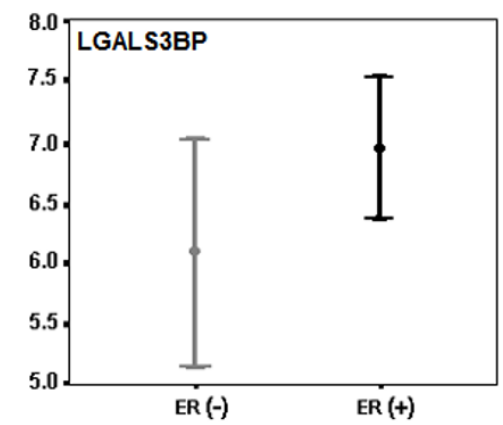

Figure I

Real time RT-PCR validation of nine over-expressed genes in $\mathbf{3 6}$ invasive breast carcinomas. a) SCUBE2 ( $=$ $0.000 \mathrm{I})$; b) SYTL4 ( $\mathrm{p}=0.0005)$; c) KIAA0882 ( $=0.0005)$; d) TSPANI ( $\mathrm{p}=0.00 \mathrm{I})$; e) CMYB $(\mathrm{p}=0.002)$; $)$ CELSR2 $(\mathrm{p}=0.0 \mathrm{II})$; g) NR4AI ( $p=0.029)$; h) ENO2 ( $=0.033)$; $)$ LGALS3BP $(p=0.079)$. Mean \pm 2 Standard Error based on Log2 transformation of real time RT-PCR values of the assayed gene relative to $18 \mathrm{~S}$ rRNA used as normalizing control. 
independent set of 36 invasive ductal breast carcinomas. In agreement with our SAGE analysis, we detected statistical differences in the over-expression of 8 out of 9 evaluated transcripts in ER $\alpha(+)$ breast tumors including: signal peptide CUB domain EGF-like 2 (SCUBE2) ( $\mathrm{p}=0.0001)$, SYTL4 ( $\mathrm{p}=0.0005)$, KIAA0882 protein $(\mathrm{p}=0.0005)$, tetraspan 1 (TSPAN1) ( $\mathrm{p}=0.001)$, myeloblastosis viral oncogene homolog $(C-M Y B)(\mathrm{p}=0.002)$, epidermal growth factorlike 2 (CELSR2) $(\mathrm{p}=0.011)$, nuclear receptor subfamily 4 (NR4A1) $(\mathrm{p}=0.029)$, and enolase $2($ ENO2) $(\mathrm{p}=0.033)$ (Figure 1). A trend of borderline significance was detected for the lectin galactoside-binding protein (LGALS3BP) $(\mathrm{p}=$ 0.079) transcript (Figure 1).

SCUBE2 (also known as EGF-like 2 or CEGP1) encodes a secreted and cell-surface protein containing EGF and CUB domains that defines a novel gene family [19]. The epidermal growth factor (EGF) motif is found in many extracellular proteins that play an important role during development, functioning as secreted growth factors, transmembrane receptors, signaling molecules, and important components of the extracellular matrix. The CUB domain is found in several proteins implicated in the regulation of extracellular process such as cell-cell communication and adhesion [20]. Expression of SCUBE2 has been detected in vascular endothelium and may play important roles in development, inflammation and perhaps carcinogenesis [19].

The CELSR2 gene (also known EGFL2) encodes a protein member of the nonclassic-type cadherins (flamingo subfamily). These 7-pass transmembrane proteins have nine cadherin domains, seven-epidermal growth factor-like repeats and two laminin A G-type repeats [21]. It is postulated that these proteins are receptors involved in cell adhesion and receptor-ligand interactions [21] playing a role in developmental processes and cell growth/ maintenance in epithelial and neuronal cells [22,23].

SYTL4 (also known as granuphilin-a or SLP4) contains an N-terminal Slp homology domain (SHD) than can specifically and directly bind the GTP-bound form of Rab27A, a small GTP-binding protein involved in granule exocytosis in cytotoxic T lymphocytes [24]. We determined that overexpression of SYTL4 is associated with ER $\alpha(+)$ tumors (Figure 1b). However, the potential role of this gene in breast carcinogenesis remains unknown.

ENO2 (also known as NSE/neuron-specific gamma enolase) encodes one of three enolase isoenzymes found in mammals. This isoenzyme was described to be expressed in cells of neuronal origin. Interestingly, in a recent report Hao et al. (2004) showed high expression of ENO2 transcripts in breast cancer lymph node metastases when compared with primary breast tumors [25].
The TSPAN1 gene (also known as tetraspanin or NET1) encodes a cell-surface protein member of the transmembrane 4 superfamily (TM4SF), involved in the regulation of cell development, activation, growth and motility. A number of tetraspanins were described as tumor-specific antigens, and it was suggested that the function of some TM4SF proteins may be particularly relevant to tumor cell metastasis [26]. Sugiura and Berditchevski (1999) observed that TSPAN1 protein complexes may control the invasive migration of tumor cells and contribute to ECMinduced production of MMP2 in breast cancer cell line [27].

NR4A1, a nuclear receptor subfamily 4, group A gene (also known as steroid receptor TR3 or NUR77) encodes an orphan member of the steroid-thyroid hormone-retinoid receptor superfamily whose members mainly act as transcriptional factors to positively or negatively regulate gene expression and play roles in regulating growth and apoptosis $[28,29]$. A role for NR4A1 in cell proliferation has been previously reported. It was shown that its expression is rapidly induced by various mitogenic stimuli such as: serum growth factor, epidermal growth factor and fibroblast growth factor [28].

Taken together, the genes that we identified and validated appear to be involved in signaling pathways related to cell proliferation, invasion and metastatic processes, but their exact role in breast carcinogenesis remains to be elucidated.

\section{Gene Ontology analysis}

Classification of genes based on Gene Ontology (GO) terms is a powerful bioinformatics tool suited for the analysis of DNA microarray and SAGE data. Analysis of GO annotation allows one to identify families of genes that may play significant roles related to specific molecular or biological processes in expression profiles [30]. We used the Expression Analysis Systematic Explorer software (EASE) [31] to annotate the 520 deregulated genes according to the information provided by the GO Consortium [30]. The GO database provided annotation for $80 \%$ (419 out of 520) of the genes identified by SAGE. Results of this analysis are shown in Figure 2 and in detail in additional data file 2 .

We observed that $31 \%$ of ER $\alpha$ associated transcripts are involved in biological processes related to cell growth and/ or maintenance, $21 \%$ are related to cell communication, and $16 \%$ are related to regulation of transcription. Approximately $16 \%$ of these deregulated genes are related to molecular functions associated with DNA binding and more specifically with transcription factor activity (10\%) (Figure 2). Interestingly, using the enrichment GO terms analysis, we identified statistical significant over-represen- 


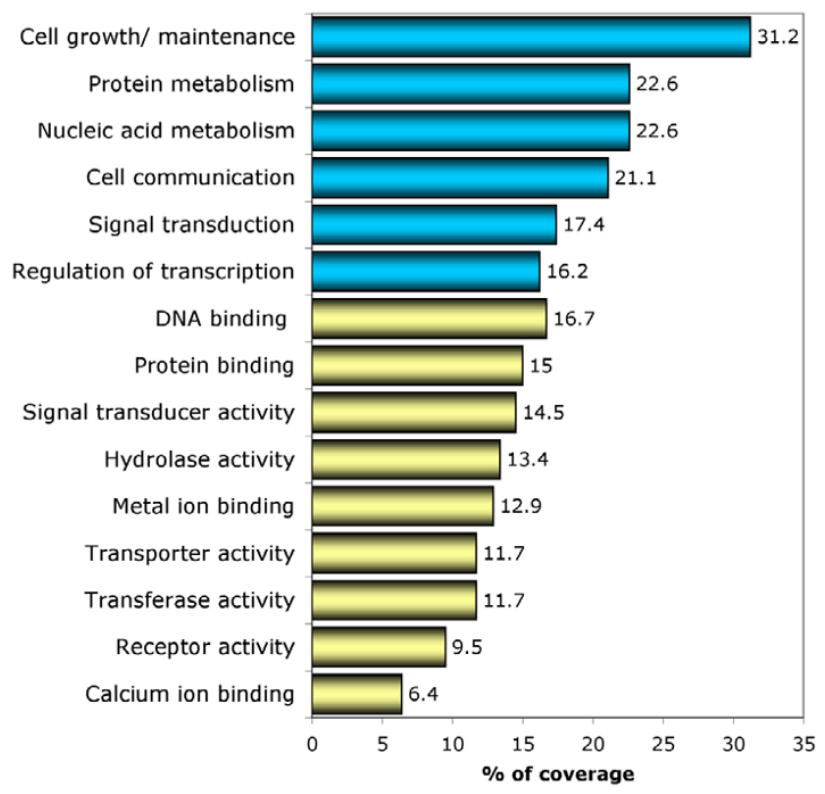

Figure 2

GO classification of the $E R \alpha$ associated genes identified by SAGE. Percent of coverage representing the percentage of genes annotated with a specific GO term related to Biological Processes (blue bars) and Molecular Function (yellow bars).

tation of specific groups of proteins including: metal ion binding proteins (54 hits out of 419 annotated genes; $\mathrm{p}=$ 0.011 ), calcium ion binding proteins ( 27 hits out of $419 ; \mathrm{p}=$ $0.032)$ and steroid hormone receptor activity related proteins ( 6 hits out of 419; $\mathrm{p}=0.031$ ) (additional data file 2). The GO cluster related to steroid hormone receptor activity proteins includes: estrogen receptor 1 (ESR1, i.e. ER $\alpha$ ), androgen receptor (AR), hydroxysteroid 17- $\beta$ dehydrogenase 4 (HSD17 34$)$, glucocorticoid receptor (NR3C1), oxysterol binding protein $(O S B P)$, and retinoic acid receptor $\alpha(R A R A)$. The observation of functionally related groups of genes identified in the SAGE dataset via GO over representation analysis allows the identification of distinct biological pathways directly or indirectly associated to estrogen response related processes and provides the basis for future mechanistic studies.

Identification of high-affinity Estrogen Response Elements We used a recently reported genome-wide high-affinity ERE database [32] to identify putative EREs in the promoter regions of the SAGE-identified 473 up-modulated genes in ER $\alpha(+)$ breast tumors. We identified 220 EREs distributed on 163 out of the 473 genes (35\%) (see additional data file 3). Seventy-two percent of these genes contain one high affinity ERE (117 out of 163) and 28\% of them contain two or more EREs in proximity to the transcriptional start sites (TSS) (46 out of 163) (Figure 3a). These EREs can be located in both coding and non-coding sequences such as was described by Bourdeau et al. [32].

The observed frequency of these elements in our study was 220 EREs in $3260 \mathrm{~kb}$ (considering a DNA window of $20 \mathrm{~kb}$ for each one of the 163 up-modulated genes with EREs). Compared with the expected frequency from random distribution of high-affinity EREs found in the genome (732 EREs in 3,069334 kb 0.8 ERE in $3260 \mathrm{~kb}$ ) (see material and methods) [32], the number of individual EREs was 270 fold higher than expected by chance $(\mathrm{p}<0.00001)$.

Fifty percent (110 out of 220) of the detected EREs mapped within a $10 \mathrm{~kb}$ region 5 ' of the TSS, while the rest mapped to 3 ' regions (Figure $3 \mathrm{~b}$ ). Approximately $68 \%$ of EREs mapped within the region between -5 to $+5 \mathrm{~kb}$ from the TSS; in agreement with those observations of Bourdeau et al. [32]. However, it remains to be determined whether distantly located EREs (e.g. - $10 \mathrm{~kb}$ from the TSS) are functional $\mathrm{E}_{2}$-ER binding sites related to transcriptional activation.

Of the validated transcripts previously discussed (Figure 1 ), we detected high-affinity EREs on the upstream or downstream regions related to the TSS of SYTL4 (-8384 bp from the TSS: tggacatcatgacct), TSPAN1 (+974 bp and +9384 bp from the TSS: tggtctgaatgaccc and aggtcattccacct respectively), CELSR2 ( +173 bp and +3607 bp from the TSS: tgctcagggtgacce and aggtcaccatgaccg respectively), and NR4A1 (-3478 bp and +4217 bp from the TSS: tgttcactctgacct).

It is interesting to note that we were unable to identify high-affinity EREs on the majority of deregulated genes (65\%) associated with a positive ER $\alpha$ status. The possibility exists that many of these genes are transcriptionally regulated by non-ERE mediated mechanisms such as those involving ER binding to the AP1 or SP1 transcription factors [33]. The AP1 transcription factor is a heterodimer formed by Jun and Fos family member proteins that binds to the phorbol diester (TPA) response element as well as to the AP1 consensus DNA sequence. In this pathway, ER plays a co-activator role for AP1 [6]. The ER/ AP-1 complex can confer estrogen responsiveness to additional subset of genes found in our dataset such as: ovalbumin (Fold change: $3 ; \mathrm{p}=0.033$ ) and $c$-fos (Fold change: $2.1 ; \mathrm{p}=0.033)$; two transcripts detected as overexpressed in ER $\alpha(+)$ breast tumors by SAGE (additional data file 1). Similarly the ER/SP1 complex confers estrogen responsiveness to genes such as: retinoic acid receptor $\alpha$ (RARA) (Fold change: 6.7; $\mathrm{p}=0.038)$, vascular endothelial growth factor (VEGFC) (Fold change: $2.6 ; \mathrm{p}=0.037$ ), insu- 
a

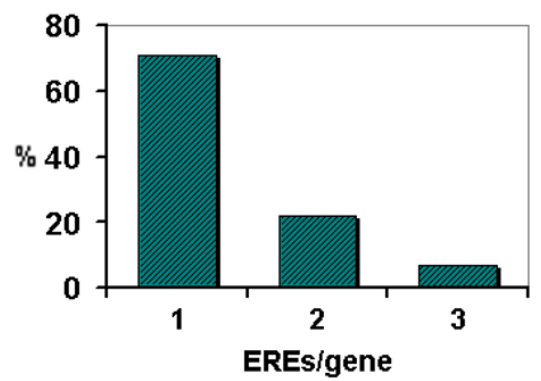

b

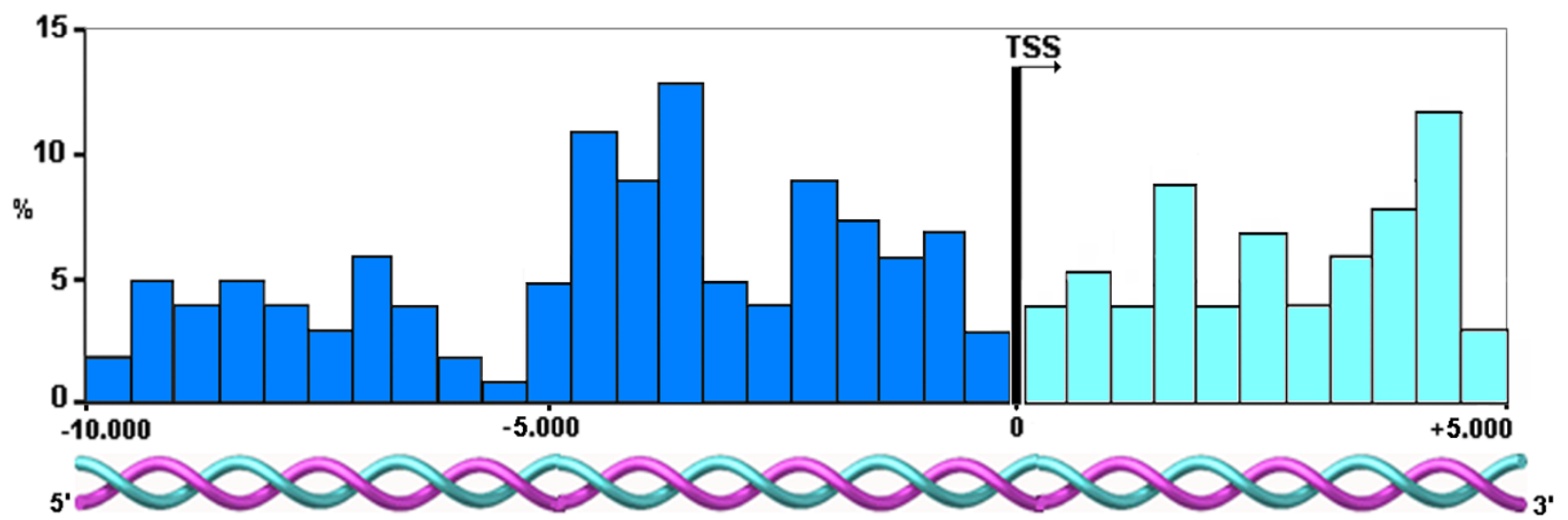

Figure 3

High-affinity EREs in ER $\alpha(+)$ up-modulated genes $(n=163)$. a) Percentage of genes according to number of EREs. b) Distribution of EREs in 5' (blue bars) and 3' (aquamarine bars) regions relative to the TSS (-I0 to $+5 \mathrm{~kb})$. Each bar represents an interval width of 500 bp.

lin-like growth factor binding protein-4 (IGFBP4) (Fold change: $2 ; \mathrm{p}=0.01$ ) and heat shock protein 27 (HSPB1) (Fold change: $2 ; \mathrm{p}=0.045)$; four transcripts detected as over-expressed in ER $\alpha(+)$ tumors in our study (additional data file 1).

An additional pathway of transcription regulation by estrogen involves the ER-related receptors (ERR), nuclear orphan receptors with significant homology to ERs, which do not bind estrogen and have unknown physiological ligands. ERRs are known to bind to the steroidogenic factor 1 response element (SFRE) and also bind to classic EREs, by means of which they exert constitutive transcriptional activity [34]. We detected over-expression of the nuclear orphan receptor NR4A1 by SAGE and subsequently validated this observation by real time RT-PCR (Figure 1g). Interestingly, and as previously mentioned, the genomic region 5 ' and 3' to the TSS of NR4A1 contain high-affinity EREs. Interaction between ERs and ERRs has been observed in the transcriptional regulation of certain genes such as the human breast cancer related gene TFF1/
pS2, the promoter of which is not only activated by ERs but also by ERRs [35].

As described, ER $\alpha$ can mediate estrogenic response through multiple genomic and non-genomic mechanisms, many of which affect proteins and pathways not necessarily directly or exclusively associated with ER $\alpha$. Thus it is worth stressing that it will the totality of deregulated proteins the ones that ultimately define the phenotype of $E R \alpha(+)$ breast carcinomas regardless of whether a "direct association" with ER transcriptional regulation exists or not.

\section{In vivo versus in vitro estrogen induced global gene expression findings}

The SAGE profiles for $\mathrm{E}_{2}$-responsive genes in MCF-7 cell line, previously reported by us [36], was compared with the ER status genes expression profile found in primary breast carcinomas. Briefly, we detected 199 transcripts differentially expressed ( $\mathrm{p}<0.01$ ) in MCF-7 treated cells, 124 were up-regulated and 75 were down-regulated 
transcripts. Basically and as reported Charpentier et al, we observed a general up-regulation cell cycle progressionrelated genes including: CCT2, CCND1, PES1, RAN/TC4, CALM1, CALM2; and tumor-associated genes such as: RFP, D52L1, TFF1/PS2, CAV1, and NDKA among others [36]. These together could contribute to the stimulation of proliferation and the suppression of apoptosis by $E_{2}-E R$ transcriptional regulation.

By comparing the in vitro (199 differentially expressed transcripts) and in vivo (520 differentially expressed transcripts) gene expression profiles, to our surprise we detect that only few transcripts: TFF1, CCND1, H19, SREBF1 and WWP1 behaved similarly (i.e. up-regulation) in both studies. This is similar to observations made previously by Meltzer and co-workers whom showed that the majority of genes regulated in cell culture do not predict ER status in breast carcinomas [11,37]. This result suggests that the estrogen-responsive pathways affected in vitro represent only a minor portion of the global gene expression profiles characteristic of $\mathrm{ER} \alpha(+)$ breast tumors. This maybe in great part the result of the heterogenous nature of bulk tumor tissue but in addition, the in vitro response of a single cell line to $\mathrm{E}_{2}$, in this particular case the widely used MCF-7 cells, may not faithfully reproduce the physiological effects of ER signaling in vivo.

\section{Cross-platform gene expression profiling comparison}

In order to identify and validate the most reliable set of genes able to discriminate breast carcinomas based on their ER $\alpha$ status, we performed a cross-platform comparison between the described SAGE dataset with two previously reported breast cancer studies based on DNA microarray methods [12,13]. van't Veer et al. [12] reported the gene expression profile of 97 primary breast tumors based on oligonucleotide microarrays containing 24,479 elements (Agilent Technologies, Palo Alto, CA, USA). In another study, Sotiriou et al. [13] reported the gene expression profile of 99 primary breast tumors using a cDNA microarray containing 7650 elements. Only files containing differentially expressed genes associated to $\mathrm{ER} \alpha$ status tumors from both microarrays studies were obtained for cross-platform comparison (see material and methods).

Among the three platforms, a total of 1686 transcripts were identified as over-expressed in ER $\alpha(+)$ breast tumors. One hundred and eighty-three genes were identified by more than one method (Figure 4; additional data file 4). Eleven of these 183 genes were identified by all three methods displaying over-expression in ER $\alpha(+)$ breast carcinomas: estrogen receptor 1 (ESR1), GATA-binding protein 3 (GATA3), mucin 1 (MUC1), v-myb-myeloblastosis viral oncogene homolog $(C-M Y B), X$-box-binding protein 1 (XBP1), hydroxysteroid 17- $\beta$ dehydrogenase 4 (HSD17B4),

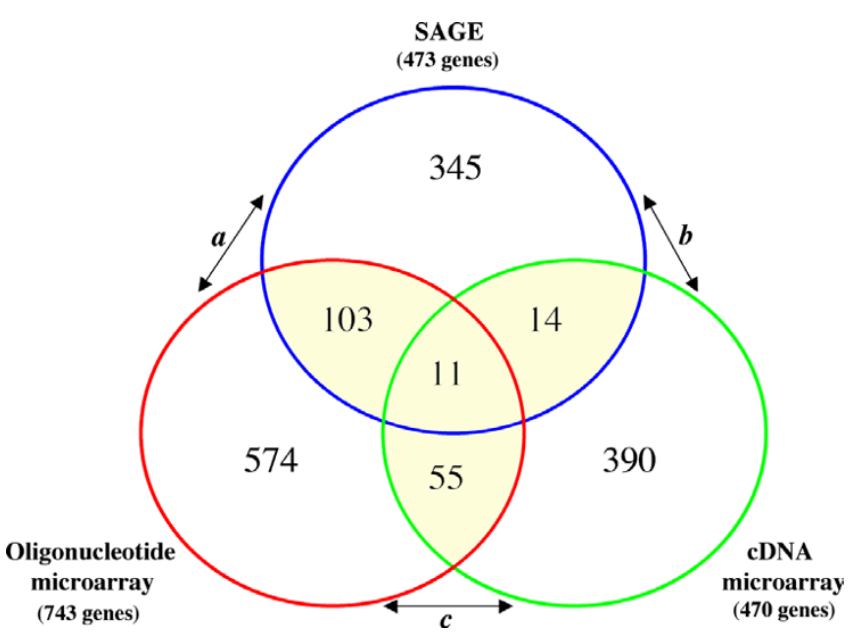

Figure 4

Cross-platform comparisons of the up-modulated transcripts in $\mathbf{E R} \alpha(+)$ breast carcinomas. One hundred and eighty-three genes were identified by more than one study, eleven of which were commonly identified across the three platforms. a) Comparison between SAGE and oligonucleotide microarray platforms [12] showing a highly significant number of overlapping genes ( $p<0.001$ ) (see table 2$)$. b) Comparison between SAGE and cDNA microarray platforms [13] ( $p>0.05)$. c) Statistically significant number of overlapping genes identified by both DNA microarrays platforms $(p<0.01)$.

BTG family member 2 (BTG2), transforming growth factor $\beta$ 3 (TGFB3), member RAS oncogene family (RAB31), START domain containing 10 (STARD10), and KIAA0089 (Table 2).

One hundred and fourteen genes were identified as overexpressed by oligonucleotide microarrays [12] and SAGE in $\mathrm{ER} \alpha(+)$ tumors, representing a non-random significant number of overlapping genes based on normal approximation to the binomial distribution $(\mathrm{p}<0.001)$ (Figure 4 and Table 2). Sixty-six genes were identified as overexpressed in ER $\alpha(+)$ tumors by both DNA microarrays platforms $(\mathrm{p}<0.01)$. The set of 25 genes overlapping between cDNA microarrays [13] and SAGE were not statistical significant $(\mathrm{p}>0.05)$.

Interestingly, we found a higher number of overlapping genes between the oligonucleotide microarray and SAGE platforms (114 genes), while only 66 genes were observed overlapping when comparing both microarray platforms. It is worth noting that $96 \%$ of the 470 genes (Figure 4 ) identified as overexpressed by the cDNA microarray method [13] were included within the total set of elements in the oligonucleotide microarray platform [12]. In 
Table 2: Transcripts identified as over-expressed in ER $\alpha(+)$ breast cancers commonly detected by cross-platforms comparison (SAGE and oligonucleotide microarrays).

\begin{tabular}{|c|c|c|c|c|c|c|c|}
\hline Gene name & Locus Link ID & Fold change & Frequency & Gene name & Locus Link & Fold change & Frequency \\
\hline TFFI* & 7031 & 51.4 & I5//8 (83\%) & SULF2 & 55959 & 2.9 & $11 / 18(6 \mid \%)$ \\
\hline SYTL4* & 94121 & 28.0 & I5//8 (83\%) & THBS4 & 7060 & 2.9 & $8 / 18(44 \%)$ \\
\hline DUSP4 & 1846 & 14.7 & $14 / 18(78 \%)$ & AZGPI & 563 & 2.8 & $9 / 18(50 \%)$ \\
\hline NATI & 9 & 11.7 & $15 / 18(83 \%)$ & BBC3* & 27113 & 2.8 & $12 / 18(67 \%)$ \\
\hline ECMI* & 1893 & 10.1 & $13 / 18$ (72\%) & NET7* & 23555 & 2.8 & $10 / 18(55 \%)$ \\
\hline KIAA0882 & 23158 & 10.1 & $18 / 18(100 \%)$ & NET6 & 27075 & 2.8 & $12 / 18(67 \%)$ \\
\hline JDPI & 56521 & 10.0 & $12 / 18(67 \%)$ & TRAF5 & 7188 & 2.8 & $9 / 18(50 \%)$ \\
\hline ESRI & 2099 & 9.8 & $18 / 18(100 \%)$ & BTG2 & 7832 & 2.7 & $9 / 18(50 \%)$ \\
\hline$\overline{\text { HDGFRP3 }}$ & 50810 & 9.8 & $12 / 18(67 \%)$ & $\overline{R N F I} 23 *$ & 63891 & 2.7 & $11 / 18(61 \%)$ \\
\hline TCEALI & 9338 & 9.8 & $13 / 18(72 \%)$ & CHAD* & 1101 & 2.6 & $12 / 18(67 \%)$ \\
\hline TSPAN I* & 10103 & 9.5 & $15 / 18(83 \%)$ & CSNKIAI & 1452 & 2.6 & |4//8 (78\%) \\
\hline C20orf103* & $24|4|$ & 9.3 & $10 / 18(55 \%)$ & $E V L$ & 51466 & 2.6 & $12 / 18(67 \%)$ \\
\hline MYLIP & 29116 & 9.3 & $11 / 18(61 \%)$ & HISTIH2BD & 3017 & 2.6 & $10 / 18(55 \%)$ \\
\hline ABCA3 & 21 & 8.9 & $10 / 18(55 \%)$ & SUSD3 & 203328 & 2.6 & $9 / 18(50 \%)$ \\
\hline SECI4L2 & 23541 & 8.7 & $9 / 18(50 \%)$ & PLAT* & 5327 & 2.6 & $8 / 18(44 \%)$ \\
\hline ANXA9* & 8416 & 8.4 & $10 / 18(55 \%)$ & RARRES3* & 5920 & 2.6 & $11 / 18(61 \%)$ \\
\hline KCTD3 & 51133 & 8.4 & $17 / 18$ (94\%) & SH3BGRL* & 6451 & 2.6 & $8 / 18(44 \%)$ \\
\hline SCUBE2 & 57758 & 7.5 & $14 / 18(78 \%)$ & TPBG* & 7162 & 2.6 & $9 / 18(50 \%)$ \\
\hline ITGBLI & 9358 & 7.1 & $8 / 18$ (44\%) & UGCG & 7357 & 2.6 & $11 / 18(61 \%)$ \\
\hline CI4orfl 68 & 83544 & 6.7 & $6 / 18(33 \%)$ & CELSR2* & 1952 & 2.5 & $8 / 18(44 \%)$ \\
\hline FBPI & 2203 & 6.7 & $14 / 18$ (78\%) & CRIMI & 51232 & 2.5 & $11 / 18(61 \%)$ \\
\hline MYB & 4602 & 6.7 & $14 / 18$ (78\%) & FLJ90798* & 219654 & 2.5 & $9 / 18(50 \%)$ \\
\hline RARA* & 5914 & 6.7 & $12 / 18(67 \%)$ & KIFI 2 & 113220 & 2.5 & $7 / 18(39 \%)$ \\
\hline CaMKIIN $\alpha$ & 55450 & 6.3 & $18 / 18$ (100\%) & LRIGI & 26018 & 2.5 & $9 / 18(50 \%)$ \\
\hline$A R^{*}$ & 367 & 6.2 & $10 / 18(55 \%)$ & LRP2* & 4036 & 2.5 & $10 / 18(55 \%)$ \\
\hline ZNF552 & 79818 & 6.2 & $16 / 18(89 \%)$ & PHFI5* & 23338 & 2.5 & $12 / 18(67 \%)$ \\
\hline MIPEP* & 4285 & 6.0 & $14 / 18$ (78\%) & HSMNPI & 55861 & 2.4 & $8 / 18(44 \%)$ \\
\hline BAI2 & 576 & 5.3 & $15 / 18(83 \%)$ & LOCI 23169 & 123169 & 2.4 & $12 / 18(67 \%)$ \\
\hline DPILI & 92840 & 5.3 & $15 / 18(83 \%)$ & PINKI* & 65018 & 2.4 & $11 / 18(61 \%)$ \\
\hline VAV3 & 10451 & 5.3 & $12 / 18(67 \%)$ & PRKAR2B & 5577 & 2.4 & $7 / 18(39 \%)$ \\
\hline KIAA0089 & 23171 & 5.2 & $17 / 18$ (94\%) & TJP3* & 27134 & 2.4 & $11 / 18(61 \%)$ \\
\hline GATA3 & 2625 & 5.1 & $15 / 18(83 \%)$ & CCNDI & 595 & 2.3 & $9 / 18(50 \%)$ \\
\hline QDPR & 5860 & 5.1 & $11 / 18(61 \%)$ & CYBRDI & 79901 & 2.3 & $10 / 18(55 \%)$ \\
\hline Clorf2I & 81563 & 4.9 & $11 / 18(61 \%)$ & KRTI8 & 3875 & 2.3 & $10 / 18(55 \%)$ \\
\hline KIAAI I 43 & 57456 & 4.9 & $7 / 18(39 \%)$ & PURA & 5813 & 2.3 & $9 / 18(50 \%)$ \\
\hline OIPIO6 & 22906 & 4.9 & $16 / 18(89 \%)$ & SREBFI* & 6720 & 2.3 & $10 / 18(55 \%)$ \\
\hline AGR2 & $1055 \mid$ & 4.6 & $10 / 18(55 \%)$ & CYB5RI & 51706 & 2.2 & $6 / 18(33 \%)$ \\
\hline MGC425I & 84336 & 4.6 & $13 / 18$ (72\%) & DLG3* & $|74|$ & 2.2 & $9 / 18(50 \%)$ \\
\hline FERIL3 & 26509 & 4.4 & $10 / 18(55 \%)$ & EEFIA2 & 1917 & 2.2 & $11 / 18(61 \%)$ \\
\hline$C 4 A$ & 720 & 4.1 & $11 / 18(61 \%)$ & GSTZI & 2954 & 2.2 & $9 / 18(50 \%)$ \\
\hline CRIP2 & 1397 & 4.0 & $15 / 18(83 \%)$ & LOCI59090 & 159090 & 2.2 & $6 / 18(33 \%)$ \\
\hline NTN4 & 59277 & 4.0 & $10 / 18(55 \%)$ & MGCIII242* & 79170 & 2.2 & $10 / 18(55 \%)$ \\
\hline GJAI & 2697 & 3.8 & $11 / 18(61 \%)$ & MGCI8216* & 145815 & 2.2 & $8 / 18(44 \%)$ \\
\hline CGI-III* & 51015 & 3.7 & $14 / 18$ (78\%) & NEILI & 79661 & 2.2 & $6 / 18(33 \%)$ \\
\hline CROT* & 54677 & 3.6 & $15 / 18(83 \%)$ & $\underline{X B P I *}$ & 7494 & 2.2 & $8 / 18(44 \%)$ \\
\hline $\mathrm{DACH}$ & 1602 & 3.6 & $13 / 18$ (72\%) & IRX5 & 10265 & 2.1 & $8 / 18(44 \%)$ \\
\hline DKFZP564DI72 & 83989 & 3.6 & $10 / 18(55 \%)$ & RAB3I & $1103 \mid$ & 2.1 & $9 / 18(50 \%)$ \\
\hline FGD3 & 89846 & 3.6 & $10 / 18(55 \%)$ & SSBP2 & 23635 & 2.1 & $7 / 18$ (39\%) \\
\hline RNASE4* & 6038 & 3.6 & $12 / 18(67 \%)$ & TGFB3 & 7043 & 2.1 & $8 / 18(44 \%)$ \\
\hline GLUL* & 2752 & 3.3 & $11 / 18(61 \%)$ & BMPRIB & 658 & 2.0 & $7 / 18(39 \%)$ \\
\hline FOXAI & 3169 & 3.2 & $10 / 18(55 \%)$ & FLJ2 I I 74 & 79921 & 2.0 & $6 / 18(33 \%)$ \\
\hline MGC7036 & 196383 & 3.2 & $14 / 18$ (78\%) & FLJ22386 & 79641 & 2.0 & $7 / 18(39 \%)$ \\
\hline MUCI* & 4582 & 3.2 & $12 / 18(67 \%)$ & HSPBI* & 3315 & 2.0 & $6 / 18(33 \%)$ \\
\hline NAVI & 89796 & 3.1 & $13 / 18(72 \%)$ & IGFBP4* & 3487 & 2.0 & $8 / 18(44 \%)$ \\
\hline
\end{tabular}


Table 2: Transcripts identified as over-expressed in ER $\alpha(+)$ breast cancers commonly detected by cross-platforms comparison (SAGE and oligonucleotide microarrays). (Continued)

\begin{tabular}{|c|c|c|c|c|c|c|c|}
\hline$\overline{R P L P I *}$ & 6176 & 3.1 & $12 / 18(67 \%)$ & MGCI5737* & 85012 & 2.0 & $8 / 18(44 \%)$ \\
\hline ALCAM & 214 & 2.9 & $9 / 18(50 \%)$ & SPARCLI & 8404 & 2.0 & $9 / 18(50 \%)$ \\
\hline HSDI 7B4* & 3295 & 2.9 & $13 / 18(72 \%)$ & STARD I0* & 10809 & 2.0 & $7 / 18$ (39\%) \\
\hline
\end{tabular}

* Genes with known or putative high-affinity EREs mapping in the vicinity of the TSS.

\# Transcripts tags changing $>2$-fold when compared with the average expression of ER $\alpha$ (-) tumors. Underlined genes correspond to the transcripts cross-validated among all three compared platforms.

other words, it appears that a better correlation was observed between SAGE and oligonucleotide arrays, than between both DNA microarray methods.

\section{Conclusion}

In summary, our comprehensive comparison of overlapping genes across different gene expression platforms provides validation for a significant number of transcripts identified as highly expressed in ER $\alpha(+)$ breast tumors. More importantly this analysis identifies the most promising biomarkers for further evaluation as ER $\alpha$ associated genes in breast cancer. Furthermore, the identified proteins may be of value as breast cancer prognostic indicators analyzed either as a group or individually. It is also likely that groups of co-regulated genes in ER $\alpha(+)$ breast cancers may be associated to the hormonal control of mammary epithelial cells growth and differentiation. Finally, a better understanding of the signaling networks controlled or associated with the estrogen response may lead to the identification of novel breast cancer therapeutic targets.

\section{Methods \\ SAGE libraries}

To perform the comparative breast cancer SAGE analysis based on ER $\alpha$ status, we analyzed 26 Stage I - Stage II invasive breast carcinomas ( $8 \mathrm{ER} \alpha$-negative tumors and 18 ER $\alpha$-positive tumors). To this end, we generated and sequenced 24 breast cancer SAGE libraries at an approximate resolution of 100,000 tags per library, combined with 2 additional breast cancer libraries (ER $\alpha$-negative tumors) downloaded from the Cancer Genome Anatomy Project - SAGE Genie database (SAGE_Breast_Carcinoma_B_95-259 and B_IDC_4) http://cgap.nci.nih.gov/SAGE/. For the generation of our SAGE libraries, snap frozen samples were obtained from the M.D. Anderson breast cancer tumor bank, and SAGE analysis was performed as previously described $[36,38]$.

\section{Data processing and statistical analysis of SAGE libraries}

SAGE tag extraction from sequencing files was performed by using the SAGE2000 software version 4.0 (a kind gift of Dr. K. Kinzler, John Hopkins University). SAGE data management, tag to gene matching as well as additional gene annotations and links to publicly available resources such as GO, UniGene, LocusLink, were performed using a suite of web-based SAGE library tools developed by us http:// spi.mdacc.tmc.edu/bitools/about/sage_lib_tool.html. In our analyses we only considered tags with single tag-togene reliable matches. To compare these SAGE libraries, we utilized a modified t-test recently developed by us [18]. This test is based on a beta binomial sampling model that takes into account both, the intra-library and the interlibrary variability, thus identifying 'common patterns' of SAGE transcript tag changes systematically occurring across samples [18].

All raw SAGE data reported as Supplementary tables in this manuscript is publicly available at http://science park.mdanderson.org/ggeg/sage Proj 9.htm.

\section{Real Time RT-PCR analysis}

Template cDNAs were synthesized on mRNAs isolated from an independent set of 36 Stage I - Stage II human breast carcinomas (13 ER $\alpha$-negative tumors and $23 \mathrm{ER} \alpha$ positive tumors) obtained from our tumor bank. Primers and probes were obtained from the TaqMan Assays-onDemand $^{\mathrm{TM}}$ Gene Expression Products (Applied Biosystems, Foster City, CA, USA). All the PCR reactions were performed using the TaqMan PCR Core Reagents kit and the ABI Prism ${ }^{\varpi} 7700$ Sequence Detection System (Applied Biosystems, Foster City, CA, USA). Experiments were performed in duplicate for each data point and 18s rRNA was used as control. Results were expressed as mean \pm 2 Standard Error based on Log2 transformation of normalized real time RT-PCR values of the assayed genes. We used ttest to compare the gene expression levels of validated genes between ER $\alpha(+)$ and ER $\alpha(-)$ breast tumors ( $\mathrm{p}<$ $0.05)$.

\section{Immunohistochemical determination of ER status}

IHC staining and ER status determination was performed by the Pathology Department, MDACC following routine immunohistochemical procedures. Briefly, five micrometer sections of invasive breast carcinomas paraffin embedded tissues were used. Endogenous peroxidase activity was blocked with $3 \% \mathrm{H}_{2} \mathrm{O}_{2}$ in methanol for $10 \mathrm{~min}$. After pretreatment with Tris-EDTA buffer, in order to block 
non-specific antibody binding, the slides were incubated with $10 \%$ goat serum in PBS for $30 \mathrm{~min}$. Primary monoclonal ER $\alpha$ antibody (ER-6F11, Novocastra, Newcastle, UK) was used at 1:50 dilution and detected following standard immunohistochemical techniques. DAB was used as chromogen and Mayers hematoxylin is used as counterstain. Scoring was performed by breast pathologist (AS). Cuttoff for positivity was determined at 5\% of tumor cells staining positively for ER (i.e. $<5 \%$ of cells the tumor was considered negative for $\mathrm{ER} \alpha$ ).

\section{Bioinformatics analysis}

For automated functional annotation and classification of genes of interest based on GO terms, we used the EASE [31] available at the Database for Annotation, Visualization and Integrated Discovery (DAVID) at http:// david.niaid.nih.gov/david[39]. The EASE software calculates over-representation of specific GO terms with respect to the total number of genes assayed and annotated. Statistical measures of specific enrichment of GO terms are determined by means of an EASE score $(\mathrm{p}<0.05)$. The EASE score is a conservative adjustment of the Fisher exact probability that weights significance in favor of biological themes supported by more genes and is calculated using the Gaussian hypergeometric probability distribution that describes sampling without replacement from a finite population [31]. This allows one to identify biological themes within a specific list of EASE analyzed genes.

\section{High-affinity Estrogen Response Elements (ERE) analysis}

To identify the occurrence of EREs within the promoter regions of up-modulated genes in ER $\alpha(+)$ breast tumors, we used a human genome-wide high-affinity ERE database http://mapageweb.umontreal.ca/maders/eredata base/[32]. This public available database contains 71,119 EREs identified across the human genome (related to 17,353 transcriptional start sites), representing the consensus ERE (5'-Pu-GGTCA-NNN-TGACC-Py-3'), and equivalent sequences with only one or two nucleotide variations from such consensus. Based on these restrictions the expected random frequency was calculated as the total number of base pairs in the human genome divided by the frequency of occurrence of a sequence with specified base pairs at 10 positions and two base pair choices at two positions $\left(3,069334246 / 4^{11}=732\right.$ high-affinity EREs $)$ [32].

\section{Comparison of gene expression patterns identified by different methodologies}

$\mathrm{ER} \alpha$ status associated genes identified in previous breast cancer studies $[12,13]$ using DNA microarray methods were compared with our SAGE findings.

All over-expressed genes in ER $\alpha(+)$ breast tumors obtained from these studies were downloaded from the corresponding web sites (http://www.nature.com/cgi-taf/ DynaPage.taf?file=/nature/journal/v415/n6871/abs/ 415530a fs.html and http://www.pnas.org/cgi/content/ abstract/100/18/10393) [12,13].

These datasets were annotated by LocusLink ID using the EASE software [26], and then compiled into one Excel spreadsheet pivotTable for comparison of overlapping genes between platforms, i.e. SAGE, Oligonucleotide and cDNA arrays. Anonymous ESTs from the microarrays platforms were excluded due to the inability to cross validate the identities between different gene expression profiles. Any combination of two lists was compared for matching gene-identity. The number and identity of genes commonly affected in two platforms (e.g. SAGE study vs. DNA microarray) was determined. We used the normal approximation to the binomial distribution as previously described [40] to calculate whether the number of matching genes derived from each cross-platform comparison was of statistical significance $(\mathrm{p}<0.05)$.

\section{Authors' contributions}

M.C.A. conceived the study idea and carried out the real time RT-PCR validations, the biostatistical/ bioinformatics analysis and writing the manuscript. Y.H., H.S. and J.A.D. carried out the breast cancer SAGE libraries and provided practical feedback on aspects of the manuscript. K.B. and S.G. developed the biostatistical and web-page base methodology. A.S. provides the tissue samples and clinical information. C.M.A. is the principal investigator and was involved in the conceptualization, design and writing of the manuscript. All authors read and approved the final manuscript.

\section{Competing interests}

The author(s) declare that they have no competing interests.

\section{Additional material}

\section{Additional File 1}

Differentially expressed genes between ER $\alpha(+)$ vs. ER $\alpha(-)$ breast carcinomas (Fold change $\geq 2 ; p<0.05$ ).

Click here for file

[http://www.biomedcentral.com/content/supplementary/1471-

2164-6-37-S1.xls]

\section{Additional File 2}

Gene Ontology overrepresentation analysis.

Click here for file

[http://www.biomedcentral.com/content/supplementary/14712164-6-37-S2.xls] 


\section{Additional File 3 \\ High-affinity EREs identified in ER $\alpha(+)$ up-modulated genes. \\ Click here for file \\ [http://www.biomedcentral.com/content/supplementary/1471- 2164-6-37-S3.xls] \\ Additional File 4 \\ Cross-platform comparison of the up-modulated transcripts in ER $\alpha(+)$ breast carcinomas. \\ Click here for file \\ [http://www.biomedcentral.com/content/supplementary/1471- 2164-6-37-S4.xls]}

\section{Acknowledgements}

The authors thank Dr. Michael MacLeod for critical reading of this manuscript. This work was supported by NIH-NCI Grant IUI9 CA84978-IAI (C. M. Aldaz) and center grant ES-07784.

\section{References}

I. Gruber CJ, Tschugguel W, Schneeberger C, Huber JC: Production and action of estrogens. $N$ Engl J Med 2002, 346:340-352.

2. Hall JM, Couse JF, Korach KS: The multifaceted mechanisms of estradiol and estrogen receptor signaling. J Biol Chem 200I, 296: $1642-1644$

3. O'lone R, Frith MC, Karlsson EK, Hansen U: Genomic targets of nuclear estrogen receptors. Mol Endocrinol 2004, I 8: | 859- I875.

4. Klinge CM: Estrogen receptor interaction with estrogen response elements. Nucleic Acids Res 2001, 29:2905-2919.

5. Qin C, Singh P, Safe S: Transcriptional activation of insulin-like growth factor-binding proteing- 4 by $17 \beta$-estradiol in MCF-7 cell: role of estrogen receptor-Spl complexes. Endocrinology 1999, 140:2501-2508.

6. Kushner PJ, Agard DA, Greene GL, Scanlan TS, Shiau AK, Uht RM, Webb P: Estrogen receptor pathways to AP-I.J Steroid Biochem Mol Biol 2000, 74:3 I I-317

7. Pedram A, Razandi M, Aitkenhead M, Hughes CCW, Levin ER: Integration of the non-genomic and genomic actions of estrogen membrane-initiated signaling by steroid to transcription and cell biology. J Biol Chem 2002, 277:50768-50775.

8. Shek LL, Dodolphin W: Survival with breast cancer: the importance of estrogen receptor quantity. Eur J Cancer Clin Oncol 1989, 25:243-250.

9. Pearce ST, Jordan VC: The biological role of estrogen receptors $\alpha$ and $\beta$ in cancer. Crit Rev Oncol Hematol 2004, 50:3-22.

10. Perou CM, Sorlie T, Eisen MB, van de Rijn M, Jeffrey SS, Rees CA, Pollack JR, Ross DT, Johnsen H, Akslen LA, Fluge O, Pergamenschikov A, Williams C, Zhu SX, Lonning PE, Borresen-Dale A, Brown PO, Botstein D: Molecular portraits of human breast tumors. Nature 2000, 406:747-752.

II. Gruvberger S, Ringner M, Chen Y, Panavally S, Saal LH, Borg A, Ferno $M$, Peterson $C$, Meltzer PS: Estrogen receptor status in breast cancer is associated with remarkably distinct gene expression patterns. Cancer Res 200I, 6 I:5979-5984.

12. van't Veer LJ, Dai $H$, van de Vijver MJ, He YD, Hart AAM, Mao M, Peterse HL, van der Kooy K, Marton MJ, Witteveen AT, Schreiber GJ, Kerkhoven RM, Roberts C, Linsley PS, Bernards R, Friend SH: Gene expression profiling predicts clinical outcome of breast cancer. Nature 2002, 4I 5:530-536.

13. Sotiriou C, Neo S, McShane LM, Korn EL, long PM, Jazaeri A, Martiat $P$, Fox SB, Harris AL, Liu ET: Breast cancer classification and prognosis based on gene expression profiles from a population-based study. Proc Natl Acad Sci USA 2003, I 8: I0393-10398.

14. Sorlie T, Tibshirani R, Parker J, Hastie T, Marron JS, Nobel A, Deng S, Johnsen H, Pesich R, Geisler S, Demeter J, Perou CM, Lonning PE, Brown PO, Borresen-DAle A, Botstein D: Repeated observation of breast tumor subtypes in independent gene expression data sets. Proc Natl Acad Sci USA 2003, 1 00:8418-8423.
15. West M, Blanchette C, Dressman H, Huang E, Ishida S, Spang R, Zuzan $\mathrm{H}$, Olson JA, Marks JR, Nevins JR: Predicting the clinical status of human breast cancer by using gene expression profiles. Proc Natl Acad Sci USA 200 I, 98: I | 462-I | 467.

16. Liu ET, Sotiriou C: Defining the galaxy of gene expression in breast cancer. Breast Cancer Res 2002, 4: |4|-|44.

17. Velculescu VE, Zhang L, Vogelstein B, Kinzler KW: Serial analysis of gene expression. Science 1995, 270:484-487.

18. Baggerly KA, Deng L, Morris JS, Aldaz CM: Differential expression in SAGE: accounting for normal between-library variation. Bioinformatics 2003, 19:1477-I483.

19. Yang R, Domingos CK, Wasserman SM, Colman SD, Shenoy S, Mehraban F, Komuves LG, Tomlinson JE, Topper JN: Identification of a novel family of cell-surface proteins expressed in human vascular endothelium. I Biol Chem 2002, 227:46364-46373.

20. Grimmond S, Larder R, Van Hateren N, Siggers P, Hulsebos TJM, Arkell R, Greenfield A: Cloning, mapping, and expression analysis of gene encoding a novel Mammalian EGF-related protein (SCUBE I). Genomics 2000, 70:74-8I.

21. Usui T, Shima Y, Shimada Y, Hirano S, Burgess RW, Schwarz TL, Takeichi M, Uemura T: Flamingo, a seven-pass transmembrane cadherin, regulates planar cell polarity under the control of Frizzled. Cell 1999, 98:585-595.

22. Formstone CJ, Little PFR: The flamingo-related mouse Celsr family (Celsrl-3) genes exhibit distinct patterns of expression during embrionic development. Mech Develop 200I, 1 09:91-94.

23. Shima Y, Kengaku M, Hirano T, Takeichi M, Uemura T: Regulation of dendritic maintenance and growth by a mammalian 7 pass transmembrane cadherin. Developm Cell 2004, 7:205-216.

24. Kuroda TS, Fukuda M, Ariga H, Mikoshiba K: The Slp homology domain of synaptotagmin-like proteins I-4 and Slac2 functions as a novel Rab27A binding domain. J Biol Chem 2002, 277:9212-9218.

25. Hao X, Sun B, Hu L, Lahdesmaki H, Dunmire V, Feng Y, Zhang SW, Wang H, Wu C, Wang H, Fuller GN, Symmans WF, Shmulevich I, Zhang W: Differential gene and protein expression in primary breast malignancies and their lymph node metastases as revealed by combined cDNA microarray and tissue microarray analysis. Cancer 2004, 100: I I I0- I I 22.

26. Berditchevski F, Odintsova E: Characterization of integrin-tetraspanin adhesion complexes: role of tetraspanins in integrin signaling. J Cell Biol 1999, I 46:477-492.

27. Sugiura T, Berditchevski F: Function of $\alpha 3 \beta$ I-Tetraspanin protein complex in tumor cell invasion evidence for the role of the complexes in protduction of matrix metalloproteinase 2 (MMP-2). J Cell Biol 1999, I46: I375-1389.

28. Kolluri SK, Bruey-Sedano N, Cao X, Lin B, Lin F, Han Y, Dawson MI, Zhang $X$ : Mitogenic effect of orphan receptor TR3 and its regulation by MEKKI in lung cancer. Mol Cell Biol 2003, 23:865I-8667.

29. Lin B, Kolluri SK, Lin F, Liu W, Han Y, Cao X, Dawson MI, Reed JC, Zhang $X$ : Conversion of Bcl-2 from protector to killer by interaction with nuclear orphan receptor Nur77/TR3. Cell 2004, I | 6:527-540.

30. Ashburner M, Ball CA, Blake JA, Botstein D, Butler H, Cherry JM, Davis AP, Dolinski K, Dwight SS, Eppig JT, Harris MA, Hill DP, IsselTarver L, Kasarskis A, Lewis S, Matese JC, Richardson JE, Ringwald M, Rubin GM, Sherlock G: Gene ontology: tool for the unification of biology. The Gene Ontology Consortium. Nat Genet 2000, 25:25-29.

31. Hosack DA, Dennis G, Sherman BT, Lane HC, Lempicki RA: Identifying biological themes within lists of genes with EASE. Genome Biol 2003, 4:R70.

32. Bourdeau V, Deschenes J, Metivier R, Nagai $Y$, Nguyen D, Bretschnei$\operatorname{der}$ N, Gannon F, White JH, Mader S: Genome-wide identification of high-affinity estrogen response elements in human and mouse. Mol Endocrinol 2004, I 8: | 4 II - I 427.

33. Gruber CJ, Gruber DM, Gruber IML, Wieser F, Huber JC: Anatomy of the estrogen response element. Trends Endocrinol Metabol 2004, I 5:73-78.

34. Vanacker JM, Bonnelye E, Chopin-Delannoy S, Delmarre C, Cavailles $\mathrm{V}$, Laudet V: Transcriptional activities of the orphan nuclear receptor EER alpha (estrogen receptor-related receptoralpha). Mol Endocrinol 1999, I 3:764-773. 
35. Lu D, Kiriyama Y, Lee KY, Giguere V: Trasncriptional regulation of estrogen-inducible pS2 breast cancer marker gene by the ERR family of orphan nuclear receptors. Cancer Res 200I, 6I:6755-676I.

36. Charpentier AH, Bednarek AK, Daniel RL, Hawkins KA, Laflin KJ, Gaddis S, MacLeod MC, Aldaz CM: Effects of estrogen on global gene expression: identification of novel targets of estrogen action. Cancer Res 2000, 60:5977-5983.

37. Cunliffe HE, Ringner M, Bilke S, Walker RL, Cheung JM, Chen Y, Meltzer PS: The gene expression response of breast cancer to growth regulators: patterns and correlation with tumor expression profiles. Cancer Res 2003, 63:7I58-7I66.

38. Abba MC, Drake JA, Hawkins KA, Hu Y, Sun H, Notcovich C, Gaddis $S$, Sahin A, Baggerly K, Aldaz CM: Transcriptomic changes in human breast cancer progression as determined by serial analysis of gene expression. Breast Cancer Res 2004, 6:R499-R5 I 3 .

39. Dennis G, Sherman BT, Hosack DA, Yang J, Gao W, Lane HC, Lempicki RA: DAVID: Database for Annotation, Visualization, and Integrated Discovery. Genome Biol 2003, 4:R60.

40. Smid M, Dorssers LC], Jenster G: Venn Mapping: clustering of heterologous microarray data based on the number of cooccuring differentially expressed genes. Bioinformatics 2003, 19:2065-207|.

Publish with Bio Med Central and every scientist can read your work free of charge

"BioMed Central will be the most significant development for disseminating the results of biomedical research in our lifetime. "

Sir Paul Nurse, Cancer Research UK

Your research papers will be:

- available free of charge to the entire biomedical community

- peer reviewed and published immediately upon acceptance

- cited in PubMed and archived on PubMed Central

- yours - you keep the copyright

Submit your manuscript here:

http://www.biomedcentral.com/info/publishing_adv.asp
BiolMedcentral 